\title{
ON THE DIALECTICAL RELATIONSHIP BETWEEN TEACHING AND LEARNING OF CRIMINAL COURSE
}

\author{
Xiang $\mathrm{Yu}^{1}$ and $\mathrm{Na} \mathrm{Li}^{2}$, Hui Wang ${ }^{3}$ \\ ${ }^{1}$ Dr, Fujian Jiangxia University, China, upcyuxiang@gmail.com \\ ${ }^{2}$ Prof. Dr., Ningbo University, China, nali321@126.com \\ ${ }^{3} \mathrm{Dr}$, Ningbo University, China \\ ${ }^{*}$ Corresponding Author
}

\begin{abstract}
The theoretical schools, knowledge system, teaching methods, learning and practice of criminal law are the fundamental factors that restrict the teaching and learning effect of criminal law. Therefore, it is necessary to sort out and find a dialectical way to properly handle the relationship between criminal law theory schools and research paradigms, criminal law theory and criminal legislation, judicial, criminal law discipline and other legal disciplines.
\end{abstract}

Keywords: Criminal jurisprudence, Education, Method

\section{INTRODUCTION}

Criminal law is one of the 14 core courses in undergraduate education of law in China, and it is also a major difficulty in the teaching and learning of law. Criminal law involves a huge theoretical system, a wide range of basic knowledge points, a lot of legal provisions and legal practice in various situations. So criminal law has always been a difficult point in the study of law. For the people living in a society ruled by law, criminal law is an essential way to understand and abide. For students who are interested in studying legal science, criminal law is the basic point that must be conquered. Based on my own teaching practice, this paper discusses the relevant problems in the study of criminal law and the countermeasures to deal with them.

\section{DEAL WITH THE DIFFERENT THEORETICAL SCHOOLS AND RESEARCH MODELS IN THE TEACHING AND LEARNING OF CRIMINAL LAW}

Criminal law has a developed legal thought and a strict theoretical framework. From a worldwide perspective, the theoretical origin of criminal law can be traced back to thousands of years ago, and the real formation of the theoretical system of criminal law has a history of 300 years. Due to the social system, legal tradition and research paradigm, there are great differences in the theoretical system of criminal law in the world today, forming several major schools of criminal law with different styles. After the founding of the People's Republic of China, Chinese criminal law was established and developed on the basis of absorbing different criminal law schools at home and abroad. After more than half a century, especially in the past 20 years, great progress has been made in the criminal law. Socialist criminal law theoretical system with Chinese characteristics has been formed. However, from the perspective of the development of criminal law, the current criminal law system in China is based on the criminal law theory of the former Soviet Union, and absorbs the criminal law theory of civil law countries in many ways. From the level of development, the study of criminal law in China is in the process of transforming from annotated criminal law to multiple criminal law based on theory and application.As far as criminal law teachers are concerned, their role is not only the 
preacher of the existing formed criminal law theory, but also an explorer of the construction and improvement of the theoretical system of criminal law in China. For the students who study criminal law, the goal he set is not to memorize the teaching materials of criminal law, but also to be the interlocutor of criminal law theories of different countries, different historical periods and different schools.

At present, there are two problems in the teaching of criminal law. One is that the teaching content is not new enough, which is reflected in the compiling template of teaching materials and the teaching contents of the lecturers. Second, Many lecturers can skillfully explain the theories of criminal law in continental law system, but they are unfamiliar when talking about the concept and norms of criminal law in common law system. When it comes to the new criminal law concepts of some countries, such as Russian or Korean , they have no idea. This situation should be changed.

As educators, first of all, they should actively understand and carefully study the research results and development trend of criminal law in different legal areas, especially the criminal law of common law system, so as to enrich the knowledge reserve and improve the degree of renewal. Secondly, they should set up a broad academic vision(Land KC, Kenneth CL,2000,pp34-67). In the teaching of criminal law, they should not be limited to the academic schools and the legal field. They should show the students the theoretical features of criminal law in different countries in a multidimensional and objective way. Thirdly, they should not only teach the basic theory of criminal law, but also inculcate the critical consciousness and rational spirit of criminal law science. As a criminal law learner, one should avoid fettering thought, and should take the initiative to absorb different and novel knowledge(Schmalleger F,2010,pp312-340). They should compare the new ideas with the existing knowledge, find the internal connection, broaden their thinking and consolidate the theoretical foundation.

\section{THE RELATIONSHIP BETWEEN CRIMINAL LAW THEORY, CRIMINAL LEGISLATION AND CRIMINAL JUSTICE SHOULD BE HANDLED WELL IN THE TEACHING AND LEARNING OF CRIMINAL LAW}

Criminal law is not a pure theory, it should provide guidance and service for legislative and judicial activities. But for a long time, China's criminal law has been compared to the "product specification" of legislation, which reflects the embarrassment of the development of criminal law: first, the lack of independent academic quality and diversified academic spirit. So it can not have a leading and substantive impact on

legislation(Hirschingerblank N, Simons L, Finley L, Clearly J. Thoerig M,2013,pp-14-28).Second, the attitude of ignoring and alienating criminal justice can not solve many problems in judicial practice. In the teaching process of criminal law, some teachers are stuck to the existing knowledge system and mode of thinking, lack of channels for information updating and thinking innovation, and can not keep up with the rapid development of legislation. Some teachers are obsessed with the construction of "impeccable" criminal law theoretical system, and are indifferent to the current judicial practice. In this situation, the teaching of criminal law is bound to be flawed. Students can master the "knowledge" of criminal law skillfully, but they are still at a loss when facing criminal legislation and justice.

At present, the development trend of criminal law is to deepen the systematization of knowledge and the application of theory. Some scholars also proposed to establish a trinity system of criminal law, including theoretical criminal law, legislative criminal law and judicial criminal law. This requires that the criminal law teachers should change their ideas and ways of thinking.

\subsection{We Should Have the Courage and Action to Keep Pace with the Times and Devote Ourselves to the Teaching of Criminal Law with Practical Guiding Significance.}

On the one hand, we should not ignore the development of criminal rule of law, but should have insight into the society, study and judge the current situation, and actively practice(Inciardi JA,1993,pp310). On the other hand, we should integrate the knowledge, pursue those new knowledge, explore new ways, and integrate criminal legislation, criminal law theory and criminal justice.

\subsection{The Teaching of Criminal Law Should Be Established on the Basis of Legislation and Justice, And The Starting Point of Thinking And Teaching Should Be Closely Linked with The Process and Results of Criminal Legislation and Justice.}

Teachers should have the academic ability to control the criminal legislation, justice and theory, and be able to use systematic and comprehensive teaching methods. It is not objective to interpret some conflicts as 
reasonable only through theoretical argumentation or from one aspect of criminal legislation or judicature. If we make full use of the methods of system analysis and system synthesis in teaching, introduce the relevant background of legislation and specific cases in judicial practice, it is easier for students to accept and correctly identify and use.

\subsection{We Should Attach Great Importance to Criminal Law Practice Courses and Various Forms of legal Practice Training.}

Such as case analysis courses, legal clinics, mock courts, etc., and take legal practice education as the first priority. We should not only actively create conditions to set up these courses, but also invest enough enthusiasm and energy to make these courses play an effective role.

As learners of criminal law, they are often unfamiliar with criminal legislation and justice, and have different deviations in the setting of learning objectives and the cultivation of learning interest. Some students hope to be able to carry out research after learning the theory of criminal law, while others are keen to solve legal problems with the knowledge of criminal law.

\section{THE RELATIONSHIP BETWEEN CRIMINAL LAW AND RELATED LEGAL DISCIPLINES SHOULD BE HANDLED WELL IN THE TEACHING AND LEARNING OF CRIMINAL LAW}

At present, in China's undergraduate teaching curriculum of law, the criminal law course is usually arranged in the early stage of four-year undergraduate study. It is arranged in the second academic year in some colleges. It is even arranged in the first year in some other colleges.

As a more complex course, We should seriously consider which stage of criminal law course should be arranged. As far as the current arrangement is concerned, we should focus on how to avoid the bad effect of learning criminal law for the beginners of law major because of the absence of professional theoretical reserves(Williams GL,1953,pp10-13).

First of all, in the teaching of criminal law, there are the basic principles and the thinking methods that must be mastered. We should properly deal with the problems what should be taught and what should not be taught, whether we should teach in detail or roughly(Fisher W, Silver E, \& Wolff N,2006,pp544-557). For example, in the teaching of the retroactivity of criminal law, students may not have learned the "legal effect" part of jurisprudence. So it should be targeted to introduce. The subjective and objective reasoning of the constitutive elements of crime is closely related to jurisprudence. There are different emphases on legal reasoning in legal logic and jurisprudence. Therefore, we can obtain the help of other courses to teach this content. Second, in the design of criminal law teaching program and the choice of teaching methods, we should carry out a step-by-step combination and maintain the flexibility. We should carry out good communication with students before and after teaching, and adjust at any time. The third is to actively participate in the research work of criminal law course reform. At present, there is a lack of quantitative data on the setting time of criminal law course, the allocation of teaching progress, the knowledge saturation in unit learning time, and the students' learning tolerance. This requires more teachers to work together to analyze and evaluate the actual teaching situation and teaching effect, and carry out empirical research. So as to provide a strong basis for the scientific planning of criminal law teaching.

For the learners of criminal law, it is very important to deal with the relationship between learning criminal law and other legal disciplines. Our suggestion is, first of all, students should establish a correct attitude. They should be fully aware of the challenges and difficulties faced by learning multiple legal disciplines and accepting criminal law as a new discipline, so as to ensure that we have the enthusiasm and enough time to study. Secondly, they should explore flexible and efficient learning methods according to their personal situation. On the one hand, they should be good at finding the key points of each legal discipline, and then establish a clear disciplinary framework in their minds. They should objectify and grid the legal knowledge system including criminal law, so as to accurately locate the knowledge system of criminal law. On the other hand, when they overcome the difficulties and doubts encountered in the process of learning criminal law, they should avoid mechanical learning. They should not only actively use the thinking methods and skills learned from other law disciplines to play the effect of learning transfer, but also focus on the analysis mode, logical structure and thinking path of criminal law. In this way, they will further improve their mastery of criminal law knowledge.

\section{ACKNOWLEDGEMENT}

This research was financially supported by the Soft science research project in Zhejiang Province" Research 
on criminal law regulation of traffic safety in zhejiang sea area under the background of "One Belt And One Road"'. (Grant NO. 2018C35013)

\section{REFERENCE LIST}

Fisher W, Silver E, \& Wolff N (2006). Beyond Criminalization: Toward a Criminologically Informed Framework for Mental Health Policy and Services Research. Administration and Policy in Mental Health, 33(5).

Hirschingerblank N, Simons L, Finley L, Clearly J. \& Thoerig M (2013). A Pilot Study of a Criminal Justice Service-Learning Course: The Value of a Multicultural Approach. The International Journal of Teaching and Learning in Higher Education, 25(1).

Inciardi JA (1993). Criminal justice. Harcourt Brace Jovanovich College Publishers.

Land KC, Kenneth CL (2000). The Ine'luence of neighborhood, peer, and family context: teajectories of delinquent/criminal offending across the life course.Bureau of Justice Statistics.

Schmalleger F (2010). Criminal justice: A brief introduction. Pearson/Prentice Hall.

Williams GL(1953). Criminal law. Stevens. 